\title{
STUDY HARD TO ACHIEVE HAPPINESS
}

\author{
Anej Pifar \\ Faculty of Economics, University of Ljubljana, Slovenia \\ anej.pifar@gmail.com \\ Kristjan Vuk \\ Faculty of Economics, University of Ljubljana, Slovenia \\ kristjan.vuk4@gmail.com \\ Tanja Istenič \\ Faculty of Economics, University of Ljubljana, Slovenia \\ tanja.istenic@ef.uni-lj.si
}

\begin{abstract}
This article examines the relationship between education and happiness in the EU countries. The results show that tertiary education and an individual's happiness are positively correlated. Furthermore, young individuals who are not employed, in education, or in training (NEET) tend to show lower levels of happiness. This means that, on average, countries with a lower rate of NEET individuals show higher perceived happiness. Additionally, the link between student-to-teacher ratio and happiness is shown to be negative, but statistically not significant.
\end{abstract}

Keywords: education, happiness, tertiary-level education, student-to-teacher ratio, youth unemployment

\section{INTRODUCTION}

In today's World, the growth of information technology and the rise of the fourth industrial revolution demands that societies amass knowledgeable workers. For a society to thrive, it needs to raise the level of education. In the last 15 years, we have witnessed a significant increase in the share of people with tertiary education attainment across the EU member states. The percentage of the population aged 25-64 with tertiary education increased from $20.8 \%$ in 2002 to $31.4 \%$ in 2017 . However, does this constant evolvement of the society result in a higher level of happiness? Are better-educated workers indeed happier workers?
Happiness has long been studied in economics, but it gained some momentum after the publication of Easterlin's (1980) paper. He came to the surprising conclusion that the level of self-reported happiness was the same among rich and poor countries and that economic growth does not necessarily lead to an increase in well-being, which is known as the Easterlin Paradox. Furthermore, to study happiness, several indices have been developed. One of the world's most famous measurements of happiness is the Happiness Index, which is used in the World Happiness Report. This is an annual report conducted by the Sustainable Development Solutions Network at the United Nations (UN) that ranks countries by their Happiness Index. 
Variables used in the index include GDP per capita and freedom to make life choices. The highest places in the ranking are usually taken by the most developed countries. This year's top three countries in the Happiness Index are Finland, Norway, and Denmark (WHR, 2018).

In spite of the importance of education, the Happiness Index does not include the educational level of a specific country in its calculation. However, we claim that a connection exists between the average educational level in a certain country and the average happines level of its inhabitants. The importance of education has also been recognized by other indexes measuring the level of satisfaction and development in different countries, such as the Better Life Index and the Human Development Index (HDI). The Human Development Index is based on the idea that the main cause of differences in development among countries is people's capabilities rather than economic growth alone. HDI tries to explain the differences in development with education, specifically with the knowledge dimension. The knowledge dimension is measured using two indicators: mean years of schooling and expected years of schooling. In addition to knowledge, dimensions that are included in the index are long and healthy life and decent standard of living (HDI, 2018). On the other hand, the main goal of the Better Life Index, practiced by the $O E C D$, is to provide an internationally comparable measure of well-being. Well-being is measured with 11 different factors, including education, which is measured with students' skills, years in education, and educational attainment (OECD, 2018).

Helliwell (2003) explained that education positively affects happiness, not so much directly, but rather indirectly through human and social capital. On the other hand, Clark and Oswald (1996) showed that more-educated individuals can be less happy due to the "overeducation effect." Although a wide array of literature has been written on the topic relating happiness and education, the results are quite ambiguous. This is one of the reasons that governed our decision to study this relationship and possibly contribute to clarification of this specific problem.

\section{LITERATURE REVIEW}

\subsection{Tertiary education and happiness}

Happiness can be defined as a sense of life satisfaction, and it relies upon fulfilling intrinsic needs, which cannot be much altered by one's surroundings and current life situation (Veenhoven, 1991). This opposes the ancient idea that happiness is relative. Research in favor of this theory was carried out by Easterlin (1974), who discussed happiness in relation to income. His analysis showed that there is a positive correlation between an individual's income and happiness within countries; however, there was no correlation among countries, which means that higher income does not necesarilly lead to higher levels of happiness. This is known as the Easterlin Paradox. Castriota (2006) stated that one of the possible explanations for the paradox is that with higher levels of education, GDP becomes less relevant for life satisfaction. More-educated individuals are assumed to have higher job satisfaction and a more-stimulating cultural life, which means that they tend to put less weight on obtaining material goods. Schneider (1975) came to a similar conclusion when comparing richer and poorer cities in the United States. Even though the happiest countries according to the World Happiness Report are the most developed countries, we can make some parallels with the Easterlin Paradox, arguing that the reason for a specific level of happiness might not be the level of economic development.

If we further develop Castriota's (2006) argument on the relationship between education and happiness, we see that happiness itself can be treated in two different ways. First, we can talk about hedonism (Kahmneman et al., 1999), which advocates for the "pleasure of today" and "living in a moment"; second, there is idea of eudaimonism (Wateran, 1993), which promotes the idea of selfrealization, fulfilling one's full potential.

According to those two approaches for defining happiness, we can certainly include education in the idea of eudaimonism. The importance of tertiary education for jobseekers lies in differentiation. Becker (1980) argued that there are no overeducated workers, just workers with a lack of skills. Thurow's (1975) idea was that education serves as 
a ranking tool for employers in the process of hiring new workers. The higher the rank, the greater is the possibility for a candidate to get a job. However, the literature (e.g., Stevens \& Weale, 2004; Pinheiro \& Pillay, 2016) shows that people with higher educational attainment might be given higher wages on average. Although, on average, more-educated people earn more and consequently tend to be happier, some caution might be needed. Even if people do receive a higher income for a higher level of education, this might not translate into their higher level of happiness. A higher level of happiness might not be reached with higher income if people put more value on non-pecuniary benefits that are brought with education itself, as argued by Chen (2011).

Cunado and Perez de Gracia (2012) found a positive effect of education on happiness. They analyzed 2,563 Spanish individuals in 2008. First, they controlled for several socio-economic variables and found a positive link between education and happiness. Their second model included professional activity (employment status), and education still had a positive effect. Finally, they included income in the model. Education did not have a significant effect anymore. Their study therefore found both direct and indirect effects of education on happiness. Their third model proved the indirect effect, which can be explained as follows: individuals with higher educational attainment tend to have higher income and a lower probability of being unemployed, which brings them higher happiness. Furthermore, their research showed that education has a diminishing marginal utility. This means that an increase of educational attainment from the primary to the secondary level would bring greater additional happiness than an increase from the secondary to the tertiary educational level.

In contrast, Oswald and Clark (1996) conducted a study of approximately 5,500 UK workers and found a negative and significant relationship between level of education and life satisfaction. The higher the level of education, the higher was the chance of an individual being unhappy. The possible explanations for this pattern might be that people with a higher level of education might have higher expectations about a job, which are more demanding to fulfill. It could also be that some workers are over-qualified for the job, and this consequently leads to a lower level of life satisfaction.

Even though the past literature connecting happiness and education does not provide a unique conclusion about the direction of education affecting happiness, we believe that the relationship between both variables is positive. Based on that, we propose the following hypothesis:

\section{H1: There is a positive correlation between tertiary education attainment and happiness.}

\subsection{NEET and happiness}

Unemployment among youth seems to be one of the biggest problems in society nowadays. With the rate of young people not in employment, education, or training (NEET), Eurostat captures the percentage of a population of a specific age and sex that is neither employed nor in further process of education or training. In 2017 the average value of NEET for persons in the age group 15-34 in the EU28 countries was $14.7 \%$, which is quite close to prerecession levels (for example, $14.4 \%$ in 2007). However, differences among European countries are quite significant. The value of NEET ranged from $6.9 \%$ in Sweden to $25.5 \%$ in Italy.

The main problem with youth unemployment is that young people possess a lower amount of human capital and they have lower skills in general. Younger workers can therefore easily fall into the experience trap, which describes the situation in which employers are seeking workers with experience. As a consequence, it takes longer for market entrants to be hired and thus they cannot get the required experience (Bell \& Blanchflower, 2015). Additionally, because they have fewer work skills and lack seniority that protects adult workers in the state of economic swings, young workers are more likely to be laid off. Such a situation significantly influences young workers' levels of happiness. In Greece, for example, where youth unemployment was one of the most perennial problem when the recession hit, the general decrease in happiness across all age groups (based on a Eurobarometer Survey) was 0.32 points (from 2.66 to 2.34). This decrease was the largest among European Union 
states comparing pre-recession (2000-2007) and post-recession (2008-2012) times (Bell \& Blanchflower, 2015).

It is also not uncommon that especially young individuals might go through times of anxiety because of concerns about the future, as shown by Blivina \& Vial'shina (2017). In their research they found that $48.4 \%$ of young jobseekers reported that they have gone through a high degree of anxiety. Additionally, the level of anxiety (also showing unhappiness) might be higher among more-educated individuals. This can be explained by distinguishing between economic and non-economic costs of education. Economic costs are associated with tuition fees, expenditures, and opportunity costs of studying (in the form of foregone earnings that could have been earned if working), whereas non-economic costs can be represented by the amount of effort put into studies. Because educated individuals tend to have higher costs of education, it is intuitive that more-educated individuals tend to report lower levels of subjective well-being (SWB) during economic downturns. In economic downturns unemployment is higher, which brings more disutility to more-educated individuals because of their greater investment in human capital (see Clark \& Oswald 1996; Striessing, 2015).

In this respect, youth unemployment can become a "constant scar, rather than a temporary blemish" (Ellwood, 1982). This permanent scar can be also reflected in lower income later on. Mroz \& Savage (2006) investigated the effects of youth unemployment on labor market outcomes in the U.S. Using National Longitudinal Survey of Youth (NSLY) data from 1979 , they showed that a 26-week unemployment spell experienced in the last year can lead to a wage penalty of around $4.7 \%^{1}$. According to dual labor market theorists, wage reduction can be seen as a cost of foregone human capital. Mroz \& Savage (2006) provided an alternative explanation, which can be connected with the increase in costs tied to on-the-job training for those who recently experienced unemployment. They found that the effect is not permanent and it diminishes over a time span of around four years. In addition, Ellwood (1982) argued that the pattern from the early labor market persists in the future, which means that a young individual who experienced poor labor records will have consequently lower labor records later on. Gregg (2001) found that an individual who experienced three months of unemployment before the age of 23 will probably experience an additional two months of unemployment between the ages of 28 and 33 .

When talking about the effect of unemployment on happiness, we should consider the problem from two different points of view: the individual (personal) level and the macro-level. The latter can be further divided. An increasing level of unemployment in the economy implies an increasing number of unhappy individuals. As a consequence, the increase of unemployment on a macro-level implies higher uncertainty and higher fear of losing a job for employed people. This fear of losing a job leads to a further decrease in the level of happiness (Ohtake, 2012).

Although many studies have concluded that unemployment makes people unhappy, this is not always the case. For example, a Finnish cross-sectional study comparing unemployment and SWB in 1990, 1996, and 2000 showed that although the unemployment rate in the 1990s considerably increased (from $3 \%$ to $17 \%$ ), this increase was not followed by a decrease in the mean level of SWB. Some patterns can be recognized. Unemployment had a smaller effect on those who perceived themselves as happier before, whereas the decline of happiness in people who perceived themselves as moderately happy was more significant. These results might be specific to Finland because high unemployment persisted as a result of a great depression in early 1990s. In cases of high and persistent unemployment on a national level, unemployment (of longer duration) could become less stigmatized (Böckerman \& Ilmakunnas, 2005). Clark (2006) found evidence that when there is a higher level of unemployment in some area, its impact on SWB is smaller.

\section{H2: There is a negative correlation between NEET rate and happiness.}

\footnotetext{
1 When transformed to numbers, this results in a wage reduction of more than $\$ 1,500$ in 2002 U.S. dollars, assuming 2,000 hours worked at an average wage rate of \$16.42 (2002 dollars) in 1993.
} 


\subsection{Effect of student-to-teacher ratio on happiness in higher education}

There is a general assumption that class size has an important influence on students' performance. The majority of studies have focused on lower levels of education, such as kindergarten and the elementary level. One of the most famous studies was the Tennessee STAR (Student-Teacher Achievement Ratio) test that ran from 1986 to 1989 (Monks \& Schmidt, 2010). This study observed pupils from kindergarten to third grade. The tests were conducted by first dividing the students into classes of 13-17 pupils and classes of 22-25 pupils. Then every year the students took tests, and the results from the smaller classes were compared with the results obtained in larger classes. The study encompassed around 6,500 pupils in about 300 classes at approximately 80 schools. The research tested the achievement of pupils in the fields of reading, mathematics, and basic study skills (Mosteller, 1995). The results showed that those pupils who were in smaller classes performed better on standardized tests in mathematics and reading than did those who were in larger classes. Krueger (1999) came to similar conclusions. His research was based on results achieved by pupils on the Stanford Achievement Test. Pupils were observed through four years of schooling, and it was shown that pupils who were in smaller clases outperformed their peers in larger classes in mathematics and reading by 0.2 and 0.3 standard deviations, respectively. The STAR test was also subjected to criticism. One of the main arguments was that some of the pupils were reassigned to other classes, either because of behavior problems or at the request of parents (Monks \& Schmidt, 2010).

Achilles et al. (1995) performed research in North Carolina in 1991. They observed pupils through the first three years of schooling. Their research also showed that pupils in smaller classes outperformed their peers in larger classes by 0.45 and 0.56 standard deviations on reading and mathematics tests, respectively. More-recent studies also came to similar conclusions. Nandrup (2016) investigated the effect of class size on performance throughout attendance at compulsory school in Denmark. The main focus was on lower (grades 1-3) and upper (grades 4-6) primary levels and the lower secondary school level (grades 7-9), with a sample size of roughly $900,000^{2}$ pupils in $2^{\text {nd }}, 3^{\text {rd }}, 6^{\text {th }}$, and $8^{\text {th }}$ grades. The data encompassed all pupils in the Danish school system and their results on standardized tests in reading and math (physics/chemistry); the data were collected by The Danish Ministry of Children and Education. The impact of class size was estimated through enrollment rates. The research concluded that there was negative effect of class size, although a modest one. A statistically significant influence was recognized only at the primary level; at the secondary level, class size had no significant effects on performance. Based on these results, pupils in $2^{\text {nd }}$ and $6^{\text {th }}$ grades might particularly benefit from class-size reductions, whereas a class-size increase in $8^{\text {th }}$ grade should not have a negative effect on pupils' performance.

From this research, one could conclude that this pattern holds also for higher levels of education. Because students are not incentivized to take standardized tests, measures taken in research are usually based on student grades and students' satisfaction with an instructor or course. One such example is the study by Bedard and Kuhn (2008), which examined student evaluations of economic courses at the University of California, Santa Barbara from fall 1997 to spring 2004. They found a highly significant negative correlation between class size and assessments of instructor effectiveness. Furthermore, Bandeira et al. (2009) studyied the relationship between class size and student performance. They found robust evidence that class size has a negative effect on students' performance (academic achievement). They also stressed that a wide range of class sizes exists for which a reduction in class size would have a very limited effect. However, they found that reducing the largest classes (more than 100 students) would significantly improve students' performance. This conclusion is quite important because better student performance can lead to higher overall life satisfaction, as

\footnotetext{
2 Out of 965,136 observations in either 2 nd, 3rd, 6th, or 8th grade, 71,701 observations were excluded due to missing results from standardized tests
} 
shown by Rode et al. (2005). They collected data from 673 students at Midwestern University and found that students who were more satisfied with their lives tended to perform better than their lesssatisfied peers. Life satisfaction might be a better predictor of student performance than is university satisfaction, because there is an effect of lower leisure satisfaction due to studying, and time spent socializing is time not spent studying. When controlling for leisure satsifaction, academic performance (measured by GPA) was found to have a significant effect on overall life satisfaction.

On the other hand, it can be argued that some other factors have a more important effect on students' performance and satisfaction with a course (program) than does class size. Gilbert (1995) found that an instructor's speaking ability, energy level, organization, and concern for students are more important factors that contribute to the quality of education. From this it can be concluded that small classes do not necessarily lead to higher quality of education. What really matters is what happens in the class and what approach an instructor uses for imparting the subject to students. Based on the literature, we thus propose the following hypothesis:

\section{H3: There is a negative correlation between stu- dent-to-teacher ratio and happiness.}

\section{METHODOLOGY}

This paper investigates the correlation between average happiness of individuals and other variables of interest in the EU-28 countries. The correlations are first presented descriptively in scatter plots and then by calculating Pearson correlation coefficient. The happiness score was taken from the latest World Happiness Report (2018). This report based the overall ranking of several countries around the world on Gallup World Poll Surveys from 2015 to 2017. The happiness score was estimated using six different variables that help to achieve higher wellbeing of individuals: income, healthy life expectancy, social support, freedom, trust, and generosity. However, we claim that the educational level of individuals influences their happiness as well. Therefore, we first correlated happiness score with the percentage of population aged 25-64 having a tertiary education. The data from 2017 were retrieved from Eurostat for all $28 \mathrm{EU}$ countries. Furthermore, because it is not only the level of education that matters for people but also their activity using their knowledge, we additionally correlated happiness score with the percentage of young people aged 25-34 neither in employment nor in education and training (i.e., NEET rates). The NEET rates from 2016 were taken from Eurostat. Next, we assumed that the quality of the educational system influences individuals' desire to attain a higher educational level. Higher quality of the educational system increases individuals' capacity and their feelings of fulfillment. As a result, individual level of happiness increases. In order to study the correlation between happiness and quality of the educational system, we correlated the happiness score with the Eurostat data on student-to-teacher ratio and academic staff in tertiary educational level. To include as many countries as possible in the analysis, the data on student-to-teacher ratio were taken from 2015. We ended up with 25 EU countries, because there were no data for Ireland and Greece and we excluded Croatia, which had incomparably high values of the ratio.

\section{RESULTS}

\subsection{Level of Happiness in EU countries}

Based on the World Happiness Report, we ranked the EU-28 countries with respect to the score each country achieved. The scores that countries achieved in the report were then ranked into seven classes, each covering 0.50 points. This study included the United Kingdom because, formally, it is still part of the EU.

According to the results of the World Happiness Report, the "happiest" country is Finland, which achieved an average of 7.63 points. The second and the third happiest countries are Denmark and the Netherlands, with 7.56 and 7.44 points, respectively; Sweden was ranked fourth. Figure 1 shows that the Nordic countries are considered to be the happiest countries in the EU. The dominance of the Nordic countries remains even when all 156 countries selected in the Happiness Report are included. 
Figure 1: Ranking of 28 EU countries by happiness score

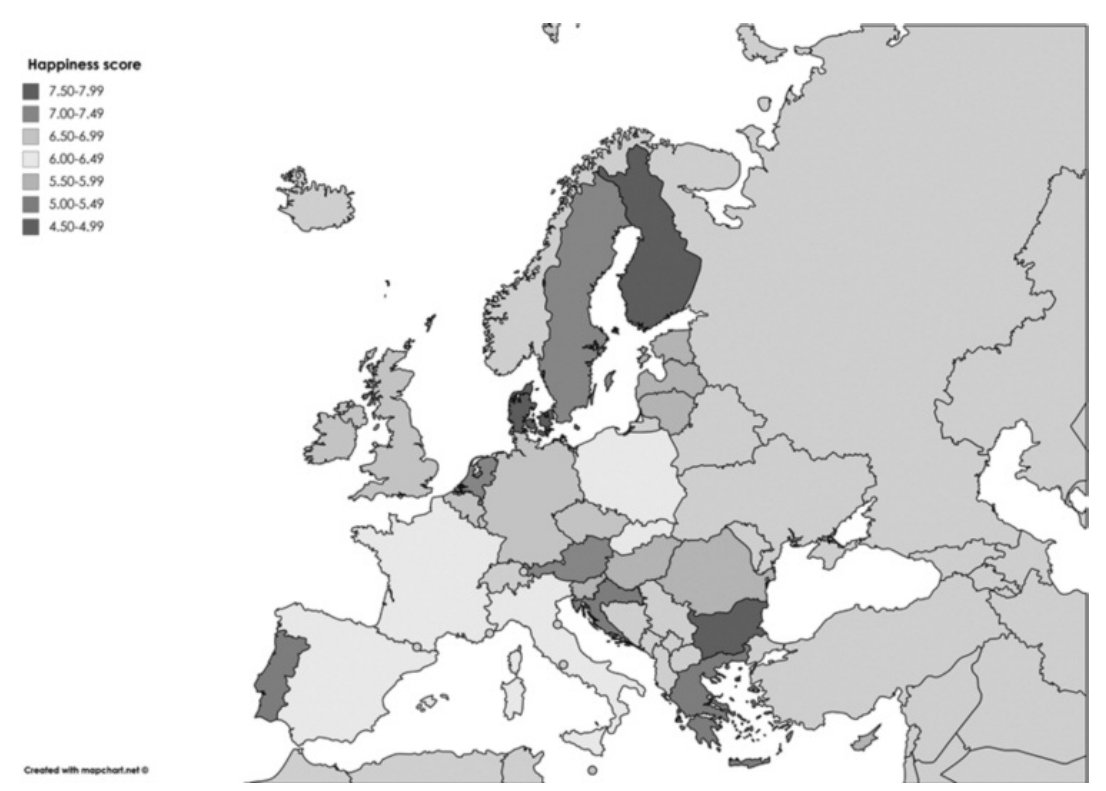

Source: World Happiness Report, 2018.

On the other hand, at the bottom of the ranking is Bulgaria, which is considered to be the least happy country in the EU, with 4.93 points. Bulgaria is also considered to be one of the least developed countries in the EU, with GDP per capita 51\% below the EU-28 average level (Eurostat, 2017). The gap between Bulgaria and Croatia, the next least happy country, is rather large (0.39 points). Bulgaria and Croatia are then followed by Greece, with 5.36 points. The rating for Slovenia (5.95 points) is shared by two other countries (Lithuania and Romania), which puts Slovenia in $18^{\text {th }}$ place on the Happiness Index among all the European Union countries. Figure 1 shows that the least happy countries are mainly in the east, whereas the happiest countries are concentrated in the northern part of the European Union.

\subsection{Happiness and tertiary education}

The percentage of tertiary-educated individuals aged 25-64 varies significantly among EU countries, from $17.5 \%$ in Romania to $44.0 \%$ in Ireland. In addition to Ireland, at the top of the ranking is another liberal country, the UK, but also the Nordic countries, such as Finland and Sweden. With $32.3 \%$ of individuals having tertiary education, Slovenia belongs to the lower half of the ranking list.
Figure 2 shows that the Nordic countries have high levels of both happiness and percentage of tertiary-educated population. In contrast, Baltic countries (such as Lithuania and Estonia) and Cyprus have high levels of tertiary-educated individuals but relatively low happiness scores. Regarding the percentage of tertiary-educated population, the position of Slovenia is similar to that of Austria and Germany; however, Slovenia has a much lower happiness score compared to the other two countries. The average educational level is the lowest in some Mediterranean countries (such as Italy and Portugal) and also in some post-Communist countries (such as Slovakia, Hungary, the Czech Republic, and Croatia); however, Portugal and Croatia have relatively low levels of happiness, whereas the Czech Republic has a relatively high level of happiness.

A positive correlation exists between happiness score and percentage of tertiary-educated individuals in the EU-28 countries. Based on Pearson correlation coefficient $(r=0.475)$, there is a statistically significant low positive correlation between happiness and level of education ( $p$-value for a two-tailed test equals 0.011 ). 
Figure 2: Happiness score and percentage of tertiary-educated population aged 25-64, EU-28 countries

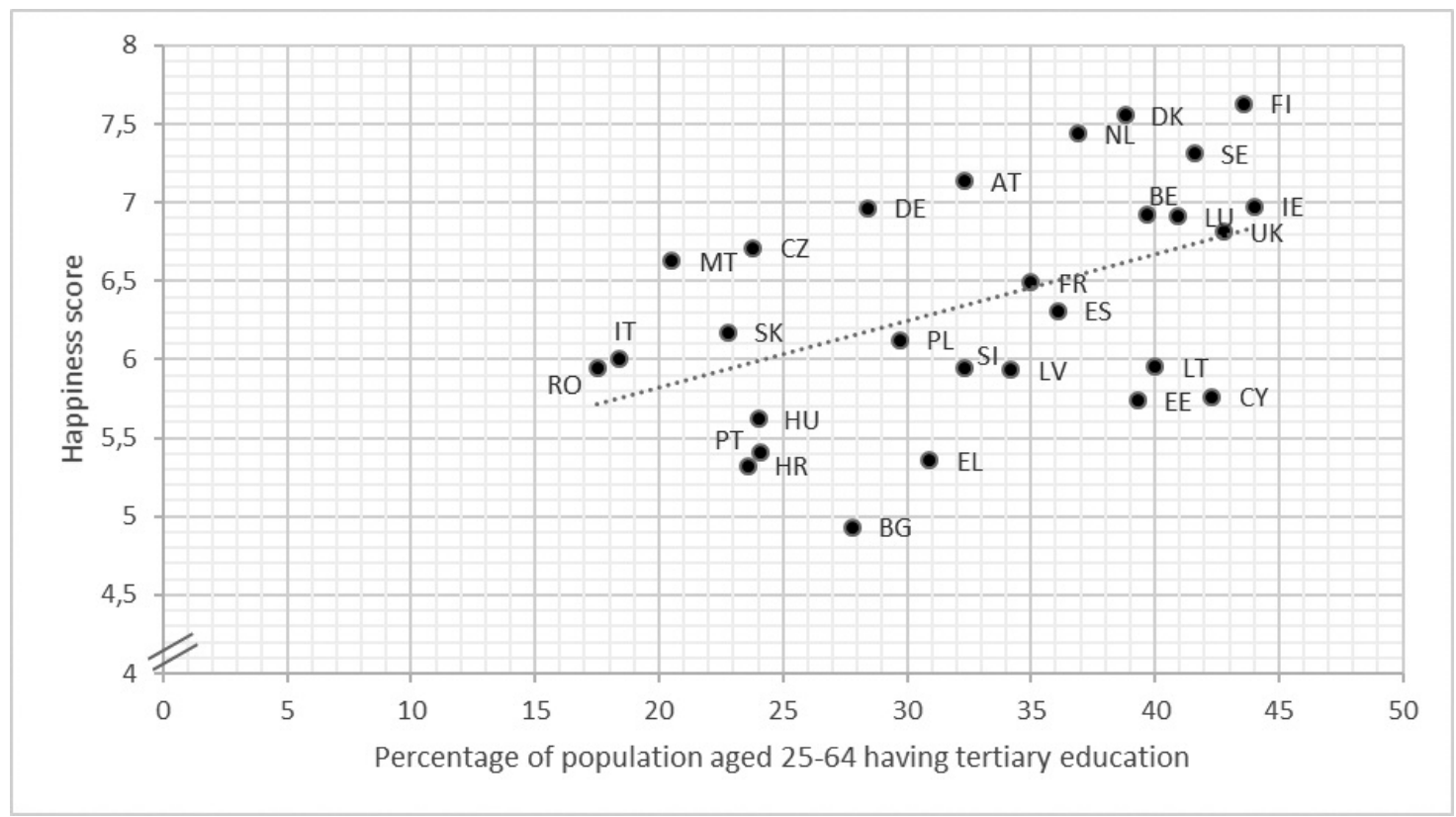

Sources: World Happiness Report, 2018; Eurostat, 2018 .

\subsection{Happiness and young individuals' involvement in activities}

This subsection measures the correlation between happiness score and young individuals' involvement in activities by percentage of individuals aged 25-34 that are neither employed nor enrolled in education. The NEET rates are the highest in Greece and Italy, representing $33.4 \%$ and $31.4 \%$ of the young, respectively. On the other hand, the NEET rates range from only $7.8 \%$ to $10.9 \%$ in Sweden, Luxembourg, and Denmark. Similarly, in Slovenia the NEET rate is relatively low, accounting for $14.1 \%$ of young individuals.

Figure 3 shows a negative relationship between happiness and NEET rates. This means that countries with lower shares of young individuals not involved in employment or education have higher general levels of happiness. The Nordic countries have the highest levels of happiness but the lowest NEET rates. Germany and Austria have a similar situation. In contrast, Mediterranean countries and some post-Communist countries (such as Bulgaria and Croatia) have relatively high NEET rates and low happiness scores. One exception is Portugal, which has a relatively low NEET rate but a low happiness score. In this case, the Pearson correlation coefficient reveals a statistically significant moderate negative correlation between happiness score and NEET rates $(r=-0.671, p=$ 0.000 for a two-tailed test).

\subsection{Happiness and ratio of students to teachers and academic staff}

The last correlation observed quantifies the relationship between quality of educational system and happiness. The quality of the educational system was measured by the number of students per teacher, and ranges from 8.2 students per teacher in Luxembourg to 23.3 students per teacher in the Czech Republic ${ }^{3}$ (Figure 4). The student-to-teacher ratio is also low in some Nordic countries (e.g., Sweden and Denmark),

3 The number of students per teacher in Croatia, 74.5, was excluded from the analysis due to transparency reasons. 
Figure 3: Happiness score and percentage of young people not in employment, education, or training (NEET rate), EU-28 countries

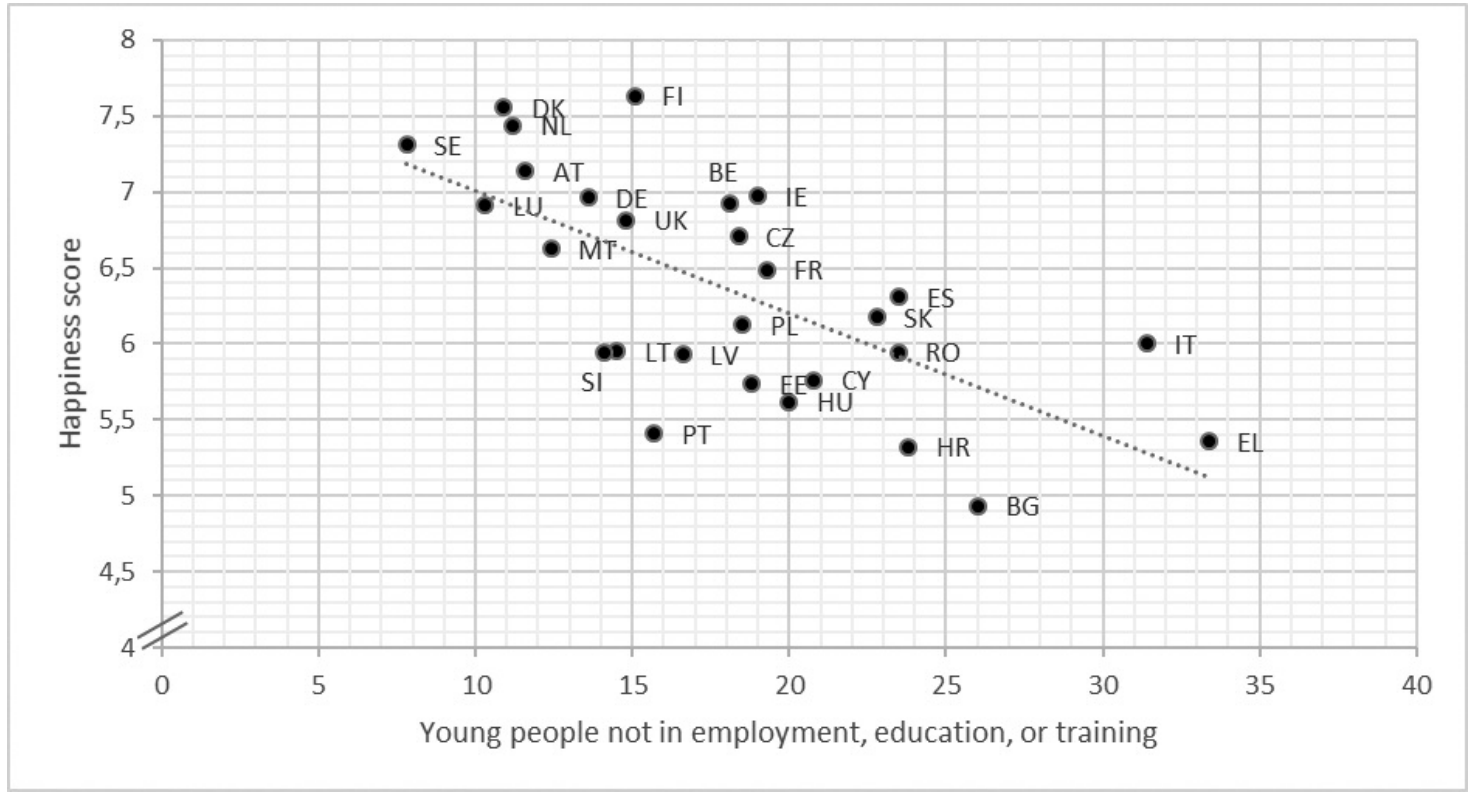

Sources: World Happiness Report, 2018; Eurostat, $2018 \mathrm{~b}$.

in Malta, and in Germany, but high in Belgium, Italy, and France. In Slovenia, the student-to-teacher ratio is relatively high, 17.2 students per teacher. The relation- ship between happiness score and student-to-teacher ratio is negative (Pearson correlation coefficient $=$ 0.158), but negligible and statistically not significant.

Figure 4: Happiness score and ratio of students to teachers and academic staff, EU-28 countries

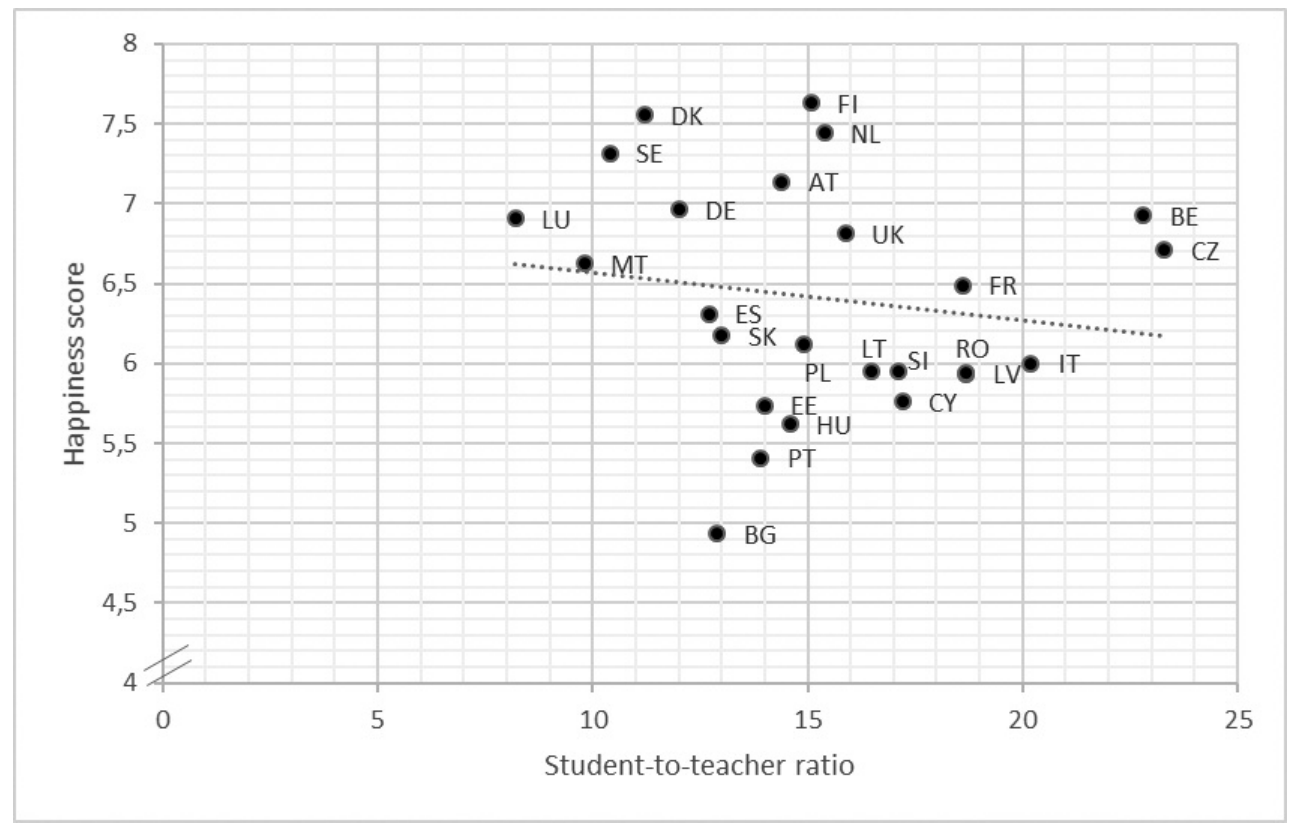

Sources: World Happiness Report, 2018; Eurostat, 2018c. 


\section{DISCUSSION AND CONCLUSION}

This study focused on happiness and its relationship with three components. First we examined the relationship of the share of people with a tertiary education to happiness. Then we focused on the relationships of people considered as NEET and of student-to-teacher ratio to happiness. Our study showed a positive correlation between happiness and the percentage of individuals with a tertiary education. In this case, the correlation coefficient $(r=0.475)$ was statistically significant, which confirms the first hypothesis, that there is a positive relationship between happiness and tertiary education attainment. These findings are in line with research by Cunado and Perez de Gracia (2012), who found a positive relationship between education and happiness, although after controlling for income this effect was not significant. Therefore, it can be concluded that education has an indirect effect on happiness. In addition, Stevens \& Weale (2004) argued that people with more education have a greater possibility to earn higher incomes, which consequentially translates into higher levels of happiness. A stronger effect of education on happiness was shown by Chen (2011), who studied the relationship in Asian countries. It was also found that the non-pecuniary benefits dominate the pecuniary benefits of higher education.

Next, we considered the correlation between people regarded as NEET and happiness. Our study showed a statistically significant negative relationship $(r=-0,671)$ between both variables, which means that, on average, in countries with lower rates of NEET people tend to have higher levels of happiness. Therefore, the second hypothesis, which assumed a negative relationship between NEET rate and happiness, is confirmed. This is again in line with vast majority of the literature (e.g., Böockermann \& Illmakunas, 2005; Ohtake, 2012). Unemployment can always be seen as a stressful situation that can have health consequences. As noted by Blivinova \& Vial'shina (2017), young jobseekers especially tend to go through periods of anxiety due to concerns about their futures, which further leads to lower levels of happiness. The theory also suggests that among the unemployed, more-educated people tend to be less happy due to the economic and non-economic costs spent attaining their levels of education (Striessing, 2014).
Additionally, we focused on the importance of student-to-teacher ratio on happiness. Our study showed a negative relationship $(r=-0.158)$ between these two variables. The result was statistically insignificant, which means that the third hypothesis, which assumed a negative relationship between student-to-teacher ratio and happiness, cannot be confirmed. Much has been written on that topic, showing a negative relationship between class size and performance. One of the most famous studies was conducted in Tenneessee (U.S.), which studied the impact of class size in elementary school on performance using STAR testing (Mosteller, 1995). It can be argued that smaller classes lead to better performance of students, because the instructor (professor) can devote more attention to students and thus motivate them to put more effort into studying. Thus when students felt that the professor was interested in their progress, this led to better perceptions of professors and also to higher levels of happiness among the students, which is a consequence of improving students' personal growth and self-development (Gilbert, 1995). However, Gilbert (1995) noted that one must be careful when analyzing the impact of class size on student performance, because other factors such as the energy level, speaking ability, and accessibility of an instructor can play an even larger role than class size.

\subsection{Implications}

We consider happiness to be an important field to study. Studying the link between happiness and education can significantly contribute to redesigning study programs and methods of teaching at lower levels of education. It is important to focus more on achieving happiness, especially among students, because this would result in better performance of students in the area of education as well as in better satisfaction with life. Because the results did not show a significant impact of class size on the happiness of students, we believe that it is perhaps better to take a different approach toward teaching, or as Gilbert (1995) nicely captured the idea, what matters is what is going on in the class.

In line with the results that we obtained, we thus encourage policymakers to further encourage educational attainment, especially at the tertiary level, because this can further lead to people being happier in general. 


\subsection{Limitations and future research}

We are aware that there are some limitations to this study which should be considered in future research. The data used were not from exactly the same year. The World Happiness Report 2018 calculated the happiness score based on nationally representative rankings for 2015-2017, whereas data retrieved from Eurostat about the share of people with tertiary education, NEET, and student-to-teacher ratio were from 2017, 2016 and 2015, respectively. We do not consider this to be a serious drawback, because these variables do not change dramatically over time. Furthermore, we compared the happiness scores of EU member states for a single year. It would be interesting to take time-series data for a longer period and examine if there are patterns in the evolution of happiness.
Furthermore, because countries differ substantially in the level of happiness score, it would be interesting to further study the possible explanations for these differences. Another important aspect should also be studied in the future. It would be interesting to know which kind of happiness is more appreciated: hedonic (more emphasis on material goods) or eudaimonic (more focused on psychological factors such as self-actualization). Chen (2011) concluded that non-pecuniary factors affecting happiness might be more important for individuals in Asia. We believe that researching this topic in other countries as well has great future research potential.

\section{EXTENDED SUMMARY / IZVLEČEK}

Članek analizira razmerje med izobrazbo in stopnjo zadovoljstva. Po rezultatih sodeč sta tercialna izobrazba in posameznikovo zadovoljstvo pozitivno povezana. Študija je pokazala, da v večini primerov mladi, ki niso zaposleni, se ne izobražujejo ali niso na usposabljanju, kažejo nižjo raven zadovoljstva. To pomeni, da v povprečju države z nižjo stopnjo NEET (angl. not in education, employment or training) kazalnika, kažejo višjo stopnjo zaznanega zadovoljstva. Študija je pokazala negativno povezavo med kazalnikom razmerja med študenti in profesorji ter zadovoljstvom posameznika, vendar le-ta ni statistično značilna.

\section{REFERENCES}

Achilles, C.M., P. Harman \& P. Egelson (1995). Using Research Results on Class Size to Improve Pupil Achievement Outcomes. Research in Schools, Vol 2(2), pp. 23-30.

Bandeira, O., Lacrinese, V. \& Rasul, I. (2009). Heterogeneous Class Size Effects: New Evidence from a Panel of University Students. The Economic Journal, Vol. 120(549), pp. 1365-1398.

Becker, G. (1980). Human capital. Chicago: University of Chicago Press.

Bedard, K. \& Kuhn, P. (2008). Where class size really matters: Class size and student ratings of instructor effectiveness. Economics of Education Review, Vol. 27(3), pp. 253-265.

Bell, D. N. F. \& Blanchflower, D. G. (2015). Youth Unemployment in Greece: Measuring the Challenge. IZA Journal of European Labor Studies, 4(1).
Blivinova, T. V. \& Vial'shina, A. A. (2017). Youth Not in the Educational System and Not Employed. Sociological Research, 56(5), pp. 348-362.

Böckerman, P. \& Ilmakunnas, P. (2006). Elusive Effects of Unemployment on Happiness. Social Indicators Research, 79(1), pp. 159-169.

Chen, W. (2011). How Education Enhances Happiness: Comparison of Mediating Factors in Four East Asian Countries. Social Indicators Research, 16(1), pp. 117-131.

Clark, A. E. \& Oswald, A. J. (1996). Satisfaction and comparison income. Journal of Public Economics, 61(3), pp. 359-381.

Clark, A. E. (2006). A Note on Unhappiness and Unemployment Duration (IZA Discussion paper no. 2406). Retrieved from IZA, Institute of Labor Economics website: https://www.iza.org/publications/dp/2406 
Cunado, J. \& Perez de Garcia, F. (2012). Does Education Affect Happiness? Evidence for Spain. Social Indicators Research, 108(1), pp. 185-196.

Cunado, P. \& Perez de Garcia, F. (2011). Does Education Affect Happiness? Evidence for Spain. Social Indicators Research, 108(1), pp. 185-196

Easterlin R.A., McVey L.A., Switek M., Sawangfa O., Zweig J.S. (2010). The happiness-income paradox revisited. Proceedings of the National Academy of Sciences of the United States of America 107(52), pp. 2246322468.

Easterlin, R. A. (1980). Does Economic Growth Improve the Human Lot? Some Empirical Evidence. Nations and Households in Economic Growth: Essays in Honor of Moses Abramovitz, pp.89-125. New York: Academic Press

Easterlin, R.A. (1974). Does Economics Growth improve the Human lot? Some Empirical Evidence. Nations and Households in Economic Growth: Essays in Honor of Moses Abramovitz, pp.89-125. New York: Academic Press.

Ellwood, D. T. (1982). Teenage Unemployment: Permanent Scars or Temporary Blemishes?. In R. B. Freeman \& D. A. Wise (Eds.), The Youth Labor Market Problem: Its Nature, Causes, and Consequences. Chicago: Chicago University Press.

Eurostat (2018). GDP per capita, consumption per capita and price level indices. Retrieved from http://ec.europa.eu/eurostat/statisticsexplained/index.php/GDP per capita, consumption per capita and price level indices

Eurostat (2018a). Population by educational attainment level, sex and age (\%) - main indicators. Retrieved from: http://appsso.eurostat.ec.europa.eu/nui/show.do?dat aset=edat Ifse 03

Eurostat (2018b). Young people neither in employment nor in education and training by sex, age and labour status (NEET rates). Retrieved from: http://appsso.eurostat.ec.europa.eu/nui/show.do?dataset=edat Ifse 20\&lang=en

Eurostat (2018c). Ratio of pupils and students to teachers and academic staff by education level and programme orientation Ratio of pupils and students to teachers and academic staff by education level and programme orientation. Retrieved from: http://appsso.eurostat.ec.europa.eu/nui/show.do?da taset=educ uoe perp04\&lang=en

Freeman, R.B. \& Wise, D. A. (1982). The Youth Labor Market Problem: Its Nature Causes and Consequences. In R. B. Freeman \& D. A. Wise (Eds.), The Youth Labor Market Problem: Its Nature, Causes, and Consequences. Chicago: Chicago University Press.
Gilbert, S. (1995). Quality Education: Does Class Size Matter?. CSSHE Professional File. Retrieved from Educational Resources Information Centre (ERIC) site: https://eric.ed.gov/?id=ED421026

Gregg, P. (2001). The Impact of Youth Unemployment on Adult Unemployment in the NCDS. The Economic Journal, 111(475), pp. 626-653.

Helliwell, J.F. (2003). How's life? Combining individual and national variables to explain subjective well-being. Economic Modelling, 20(2), pp. 331-360.

Helliwell, J.F., Layard, R., \& Sachs, J. (2018). World Happiness Report 2018, New York: Sustainable Development Solutions Network.

Kahneman, D., Diener, E. \& Schwarz N. (1999). WellBeing: Thle Foundations of Hedonic. NewYork: Russell Sage Foundation.

Krueger, A (1999). Experimental Estimates of Education Production Functions. Quarterly Journal of Economics, Vol. 114(2), pp. 497-532.

Monks, J. \& Schmidt, R. (2010). The Impact of Class Size and Number of Students on Outcomes in Higher Education. Retrieved from Cornell University, School of Industrial and Labor Relations site: https://digitalcommons.ilr.cornell.edu/cgi/viewcontent.cgi?article $=114$ 5\&context=workingpapers

Mroz, T. A. \& Savage, T. H. (2006). The Long-Term Effects of Youth Unemployment. The Journal of Human Resources, 41(2), pp. 259-293.

OECD Better Life Index (2018). Retrieved from: http://www.oecdbetterlifeindex.org

Ohtake, F. (2012). Unemployment and Happiness. Japan Labor Review, 9(2), pp. 59-74.

Pinheiro, R. \& Pillay, P. (2016). Higher education and economic development in the OECD: policy lessons for other countries and regions. Journal of Higher Education Policy and Management, 38(2), pp. 1-17.

Rode, J.C., Arthaud-Day, M. L., Mooney, C. H., Near, J. P. Baldwin, T. T, Bommer, W. H. \& Rubin, R. S. (2005). Life Satisfaction and Students Performance. Academy of Management Learning \& Education, 4(4), pp. 421-433.

Schneider, M. (1975). The Quality of Life in Large American Cities: Objective and Subjective Social Indicators. Social Indicators Research, 1(4), pp. 495-509.

Stevens, P. \& Weale, M. (2004). Education and economic growth in Johnes, G. \& Johnes, J. (Eds.), International Handbook on the Economics of Education (pp. 164188). Edward Elgar Publishing Ltd: Cheltenham, UK.

Striessing, E. (2015). Too Educated to be Happy? An Investigation into the Relationship between Education and Subjective Well-being (Report No. 15-015). Laxenburg, Austria: International Institute for Applied Systems Analysis (IIASA). 
Thurow, L. (1975). Generating inequality. New York: Basic Books.

United Nations Development Programme (n.d.). Human Development Index (HDI). Retrieved from: http://hdr.undp.org/en/content/human-development-index-hdi

United Nations Development Programme (UNDP) (2018). Human Development Reports. Retrieved from: http://hdr.undp.org/en/content/human-development-index-hdi

Veenhoven, R. (1991). Is Happiness Relative? Social Indicators Research, 24(1), pp. 1-34.

Veenhoven, R. (2008). Healthy happiness: effects of happiness on physical health and the consequences for preventive health care. Journal of Happiness Studies, 9(3), pp. 449-469.

Vstavi Ellwood (1982), Mroz \& Savage (2006), Blivinova \& Vial'shina (2017), Gregg (2001), Striessing (2015), Ohtake (2012),

Waterman, A.S. (1993). Two Cenceptions of Happiness: Contrasts of Personal Expressiveness (Eudaimonia) and Hedonic Enjoyment. Journal of Personality and Social Psychology, 64(4), pp. 678-691. 